Данило С. АЛЕКСИЋ

Универзитет у Београду Филолошки факултет
Оригинални научни рад

Примљен: 13. 01. 2017. Прихваћен: 10. 02. 2017.

\title{
АНИМАТНОСТ И ЖИВЕ МАШИНЕ
}

\begin{abstract}
Предмет истраживања су форме акузатива једнине код именица м. рода I врсте које означавају аутономна вештачка бића (нпр. робот). Дају се релативне фреквенције конкурентних облика и семантичко-формалне интерпретације тих података, при чему се велика пажња поклања ређем, неочекиваном виду овог падежа.

Кључне речи: морфологија, именице, акузатив, аниматност, живо, неживо, робот
\end{abstract}

0. ПредмЕт и циљ. Рад је посвећен синкретизму акузатива и номинатива одн. генитива у једнинским парадигмама именица I врсте м. рода које означавају (релативно) аутономна и вештачка бића - аватар, андроид, бот, дроид, дрон, киборг, клон и робот. Циљ је да се утврде (а) релативне фреквенције сингуларских акузативних форми и (б) правила њихове дистрибуције у грађи.

1. ИсторијА ПитАњА. Избор између поменутих облика објашњава се референцијом ${ }^{1}$ именице: у начелу, ак. именица чији су референти „жива бића” има „завршетак - $a$ ” („нпр.: Видим човѐка, јѐлена, гӧлубб $[\ldots]$ ]”), док именице „које означавају било шта друго” ту „немају [...] никаквог наставка за облик”2 (Стевановић ${ }^{5}$ 1986: 190).

1.1. Према М. Стефановић (2008: 134-135), именица робот у српском језику „има различите облике акузатива, што зависи од функционалног стила у којем се појављује”: „[с]ви примери” пронађени „у делима научне фантастике и у новинама и часописима имају облик акузатива који је једнак генитиву, а они који су из техничке литературе имају акузатив који је једнак номинативу”. На српски се језик проширују Ицковичева тумачења одговарајућег руског корпуса (1980: 90-91): „синкретизам акузатива и генитива типичан [je] за језик научне фантастике и новина”, пошто су роботи „замишљени као

\footnotetext{
*daniloaleksic01@gmail.com

${ }^{1}$ В. Драгићевић ${ }^{2} 2010: 59$.

${ }^{2}$ В. т. 2.1.
} 
хуманоиди („думающие и говорящие человекоподобные существа”), и према томе су и добили најпре аниматни облик акузатива"з (Стефановић 2008: 134). Што се тиче научног стила, „када се проширила употреба оваквих машина које замењују људски рад, и када је именица робот постала технички термин, синкретизам акузатива и номинатива за специфичну област (електронику, роботику и сл.) постао је типичан и употреба тог облика је сада маркирана као професионализам". ${ }^{4}$ Додаје се да је акузатив полусложенице фото-робот ,jеднак номинативу не због утицаја професионалног стила (у полицији), већ због тога што је објекат стварно инаниматан, тј. то је цртеж” (Стефановић 2008: 134-135).

1.2. Ицкович (1980: 91) бележи и отклоне од принципа човеколикости, нпр. „паралелну употребу” у истом тексту: (а) продор аниматног ак. у „научно-популарне” текстове, „иако се ради о индустријским роботима”, тј. „аутоматским манипулаторима с програмским управљањем” (1980: 90), и (б) примере инаниматног ак. у грађи из научне фантастике.

2.1. ПристуП морФЕмици АКузАтивА. Ради једноставности, од т. 2.2 сматраће се да именице м. рода І врсте у ак. јд. или имају наставак - $a$, или немају наставак (в. Дешић 1997: 188, 192). Наиме, морфема се дефинише као емска, апстрактна јединица, која се у говору остварује морфима. ${ }^{5}$ Одатле следи да у облику во̀ а морф - $а$ изражава граматичку морфему „ном. јд.”, док код именице у клаузи Идем у град нулти морф (в. Бауер 22003: 37, Марковић 22013: 38) изражава граматичку морфему „ак. јд.”. Д Другим речима, одсуство морфа не повлачи одсуство морфеме (податка).

2.2. ТЕРмИНОЛОШКА РЕшЕњА. Због полисемичности домаћих еквивалената, ${ }^{8}$ овом се приликом као назив категорије „живо”/„неживо” (в. Дешић 1997: 185) употребљава термин аниматност (енгл. animacy), а као називи њених вредности - термини аниматан и инаниматан (енгл. /in/animate). (Ин)аниматним се, метонимично, могу прогласити и сами облици ак. јд. проучаваних именица. Форме супстантива које су посреди згодно је звати и „краћи” одн. „дужи” акузатив.

3. О одАБРАним именицАмА. Све лексеме набројане у т. 0 страног су порекла и већина њих се среће однедавно. Зато ваља укратко дефинисати једи-

\footnotetext{
3 У Чапековој драми R.U.R., исходишту именице робот, они се „споља” нимало не разликују од људи (Ицкович 1980: 90).

${ }^{4}$ Говорећи овде о језику „технике”, Ицкович (1980: 90-91) наводи примере из публикација које се не би могле сврстати међу стриктно техничке (нпр. Вечерняя Москва), чак ни кад за њих пишу и академици (Наука и жизнь).

${ }_{5}^{5}$,As with all EMIC notions, morphemes are abstract units, which are realized in speech by DISCRETE units, known as morphs" (Кристал ${ }^{6} 2008$ s. v. morpheme).

${ }^{6}$ Занемарује се питање да ли би у морфему требало увести још нпр. именичку врсту, као и да ли се уопште ради о једној морфеми, а не о двема, кумулативно реализованим (в. Марковић 22013: 143; уп. Бауер 22003: 19).

${ }^{7}$ Следи и да се у овом случају не може говорити о „нултој морфеми”. Такав појам пристајао би ситуацији када морф не носи никакву лексичку или граматичку информацију, као нпр. морф -ов- у облику градови (,,[p]razni morf” / „empty morph”; в. Марковић 22013: 46-47 одн. Бауер 22003: 329).

${ }^{8}$ Уп. ,živost” (Марковић 22013: 239).
} 
нице којих нема у једнотомном и шестотомном Матичином речнику срп. одн. „сх.” језика. ${ }^{9}$

аватар: 1. (у хиндуизму и будизму) бог који се појавио у физичком облику; 2. слика особе или животиње која представља одређену особу, на компјутерском екрану, нарочито у компјутерској игри или на друштвеним мрежама

Андроидтм: тип оперативног система, дизајниран за мобилне уређаје[...]

бот: компјутерски програм који обавља одређени задатак много пута

дроид: 1. = андроид [...]

дрон: [...] 5. летелица без пилота, контролисана са земље

киборг: (у научнофантастичним причама) биће које је делом човек, а делом машина

Ових 8 именица испитивано је првенствено да би се из морфолошког аспекта сагледале ,живе машине”. Појам живе машине могу омеђити следеће опозиције:

- вештачко : природно;

- неорганско : органско;

- аутономно : даљински контролисано; ${ }^{10}$

- материјално : виртуелно.

Прототипична жива машина била би материјалан аутономан неоргански вештачки ентитет. Табела 1 показује колико се поједина (делимично) вештачка бића уклапају у канонски модел. ${ }^{11}$ Атипичнија вештачка бића, која су ту највише ради поређења, дата су при крају.

ТАБЕЛА 1

\begin{tabular}{|c|c|c|c|c|}
\hline & вештачко & неорганско & аутономно & материјално \\
\hline робот & + & + & + & $+(-)$ \\
\hline андроид & + & + & + & + \\
\hline дроид & + & + & + & + \\
\hline бот & + & + & + & $-(+)$ \\
\hline аватар & $+(\%)$ & $+(-)$ & - & $-(+)$ \\
\hline дрон & + & + & $-(\% ?)$ & + \\
\hline киборг & $\%$ & $\%$ & + & + \\
\hline клон & $\%$ & - & + & + \\
\hline
\end{tabular}

\footnotetext{
${ }^{9}$ Значења се дају према ОР. За изворне дефиниције (на енгл.) нема простора. Изостављена су значења која нису потврђена у акузативском корпусу, а формат одредница је мењан.

${ }^{10}$ УП. овај и значењске критеријуме из 5.1 и 5.7 са способношћу „,za kretanje” и „za [voljnu, osmišljenu] akciju” коју помиње М. Ивић (в. чланак цитиран у Дешић 1997: 186).

${ }^{11}$ Ређа референција овог типа представљена је заграђеним симболом, а делимична припадност класи знаком ,\%”.
} 
„Нематеријална” машина је високо самосталан компјутерски програм (в. бот, у 5.3). Овде спадају и аутоматизовани или уживо контролисани ликови у виртуелној реалности, као у видео-играма.

Прва два критеријума не подударају се, пошто органски ентитет може бити делимично вештачки. На пример, клон више животиње је органско биће које не настаје природним путем, већ намерном модификацијом ћелија.

4. Корпус. Полазећи од 1.1, прикупљена је тројака грађа.

4.1.1. „Новински корпус” (НовК) чине текстови са медијских портала који садрже тражене речи са наставком - $а$ или без њега. Сајтови blic.rs, politika.rs и kurir.rs претражени су директно, а остали преко сајта naslovi.net. Добијено је бар 11.318 јединствених линкова ка текстовима са 96 сајтова (37\% линкова потиче са сајта Блица ${ }^{12}$ ), али неки од тих текстова нису преузети или нису преузети цели. Величина добијене сирове грађе, без (обимних) допунских корпуса, приказана је у Табели 2.

ТАБЕЛА 2

\begin{tabular}{|c|c|c|c|}
\hline & $\begin{array}{c}\text { Број карактера } \\
\text { („,no spaces”) }\end{array}$ & $\begin{array}{c}\text { Број страница } \\
\text { у Ворду }\end{array}$ & Датум \\
\hline робот & 4.709 .560 & 3.815 & $\begin{array}{c}\text { 8.3.2016. } \\
\text { (део и до 17. 7.2016) }\end{array}$ \\
\hline андроид & 3.973 .106 & 3.869 & 18. 7. 2016 . \\
\hline аватар & 3.609 .496 & 2.494 & 2. 8. 2016 . \\
\hline дрон & 2.729 .982 & 2.542 & 17. 7. 2016 . \\
\hline бот & 1.660 .618 & 1.157 & 21. 7. 2016. \\
\hline клон & 1.061 .978 & 739 & 19. 7. 2016. \\
\hline дроид & 731.017 & 428 & 23. 7. 2016 . \\
\hline киборг & 355.462 & 254 & 23. 7. 2016 . \\
\hline Укупно & 18.831 .219 & 15.298 & \\
\hline
\end{tabular}

4.1.2. „Научнофантастички” („SF”) корпус обухвата 227 књига из едиција Кентаур, Поларис, Руне и Сфинга сабраних у електронском издању „Polarisov” SF CD-ROM 2 (верзија 1.0).

4.1.3. „Научни” корпус (НК) покрива само именицу робот, а текстови из којих се он састоји наведени су у т. 5.7.

4.2. Из грађе су ексцерпиране реченице са лексемама типа робот у ак. јд. Због нпр. преношења агенцијских вести, код реченица (и наслова) из НовК било је парцијалних или потпуних дупликата. Потоњи су избацивани, а они први свођени на једну реченицу са податком о разлици, ако је та разлика

\footnotetext{
12 Латинички називи домаћих медија, осим назива̂ на страном језику, писани су ћирилицом. Примери су мењани минимално.
} 
првенствено правописна или чисто адитивна (додавање без других измена). Морфолошка или већа синтаксичка интервенција, наиме, оставља могућност да је и дати ак. јд. ауторова ,језичка одлука”.

5. РезултАти. У овој тачки износи се фреквентност аниматног одн. инаниматног акузатива, уз интерпретације од локалног значаја. Из табела се колона неког корпуса брише онда када у њему није нађен ниједан пример.

5.1. АвАTAP. Најчешћа релевантна значења су „слика” и „човеков виртуелни лик":

Više od 100 tviteraša je do sada i promenilo avatar na Tviteru u znak podrške trci. (Ало)

"World of Warcraft" je jedna od igara u kojoj igrači za sebe prvo kreiraju imaginarni, virtualni lik - avatara, kojeg potom vode kroz igru. (Мондо)

Јединица аватар 1 чешће је инаниматна зато што је њен референт статичан, иако представља особу.

ABATAP (,СЛИКА”)

\begin{tabular}{|l|c|}
\cline { 2 - 2 } \multicolumn{1}{c|}{} & НовК \\
\hline Аниматни акузатив & $\mathbf{1 9 , 0 5 \%}(4)$ \\
\hline Инаниматни акузатив & $\mathbf{8 0 , 9 5 \% ~ ( 1 7 ) ~}$ \\
\hline
\end{tabular}

Виртуелни лик сам по себи није самосталан, али је отеловљен и активан у виртуелној реалности; отуда висок постотак дужег акузатива.

ABATAP $_{2}$ („ЧОВЕКОВ ВИРТУЕЛНИ ЛИК /У ВИДЕО-ИГРИ ИЛИ НА ЧЕТУ/”)

\begin{tabular}{|l|c|}
\cline { 2 - 2 } \multicolumn{1}{c|}{} & НовК \\
\hline Аниматни акузатив & $\mathbf{5 2 , 9 4 \% ( 2 7 )}$ \\
\hline Инаниматни акузатив & $\mathbf{4 7 , 0 6 \%}(24)$ \\
\hline
\end{tabular}

Забележен је пар реченица које се битно разликују само по аниматности ове именице (,минимални пар”):

Пошто је одавно постало јасно да се играње компјутерских игара може претворити у зависност [...], у Франкфурту је покренута иницијатива за одвикавање од те „болести”, под називом „Сахрани свог аватара / svoj avatar”. (Политика / 24 сата)

Назив филма Аватар (2009) инаниматан је у 98 од 157 случајева, а име епонимичног делимично вештачког органског тела из Аватара онда када се уз то име прецизира да се ради о даљински контролисаном ентитету (у 2 од 6 , једном у апозицији ${ }^{13}$ при им. тело); када тог податка нема, могуће је да се

${ }^{13}$ УП. Стефановић 2008: 42, 143. 
(због необавештености?) аватар види као независнији, или као припадник фиктивне ванземаљске врсте према којој је уобличен.

Ova žena se [помоћу шминке] pretvara u Anđelinu Žoli, [...] avatara... (Курир)

Када им. аватар означава физичку манифестацију натприродног бића у одређеним системима (митолошким и сл.), било стварањем ${ }^{14}$ или узурпирањем тела, њен ак. јд. јавља се само с наставком - 3 пута у SF корпусу и једном у НовК.

5.2. АндРоид. Роботичари радије користе нпр. израз „,антропомиметички робот" него ову именицу, па стручни корпус са њом није прибављен. ${ }^{15}$

$$
\text { АНДРОИД }(\text { (,АНТРОПОМОРФНИ РОБОТ”) }
$$

\begin{tabular}{|c|c|c|}
\cline { 2 - 3 } \multicolumn{1}{c|}{} & НовК & SF корпус \\
\hline Аниматни акузатив & $\mathbf{7 6 , 9 2 \% ( 1 0 )}$ & $\mathbf{1 0 0 \%}(35)$ \\
\hline Инаниматни акузатив & $\mathbf{1 5 , 3 8 \% ( 2 )}$ & \\
\hline Инаниматни акузатив - само који & $\mathbf{7 , 6 9 \% ( 1 )}$ & \\
\hline
\end{tabular}

Реченице с ређим обликом гласе овако:

- Javna je tajna da NASA poseduje još savremeniji humaniodni android od japanskog

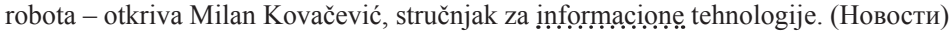

Njihov konstruktor [...] izjavio je da je u dizajnu robota bio inspirisan izgledom popularnog junaka stripova i crtaća iz šezdesetih „Astroboj”, te da mu je cilj da u budućnosti dalje sprovede minijaturizaciju ovih mașšṇa i jednog dana stvori džepni android koji ne bi bio veći od mọpịlṇog tẹlefọnạ. (PTC, 2013)

[УП.:] [...] he now wants to create a miniaturised robot that owners could carry in their pocket $[\ldots]$ (Bangkok Post, исти датум)

Android „Simroid“ koji je firma „Kokoro” razvila u saradnji sa Stomatološkim univerzitetom „Njihon“ služi kao pacijent koji odmenjuje ljude tokom obuke mladih zubara. (PTC, 2014)

[УП.:] Simroid [...] was developed by [...] company Kokoro as a dummy patient for dental students. (New Scientist, 2007)

Први би се пример, с обзиром на наведени податак о струци саговорника и на контекст (управни говор), могао тумачити као аналогија ${ }^{16}$ према инаниматном професионализму робот, мада је „humaniodni” (!) ту било редундантно.

Аутор других двеју целина је И. Мусулин, филолог. У обама чланцима употребљен је и дужи акузатив им. андроид. Из тих текстова и пратећих илустрација јасно је да се ради о роботима који подражавају човеков изглед и/или личност. У првој је реченици могућ утицај оближњих им. машина и

\footnotetext{
${ }^{14}$ Метафизичка творевина не може се сматрати вештачком, бар не у истом смислу као инжењерска (уп. нпр. стварање света ех nihilo у хришћанству).

${ }^{15}$ УП. следећи назив докторске дисертације: Моделирање и управљање антропомиметичког робота са антагонистичким погонима у контактним и бесконтактним задацима.

${ }^{16}$ Уп. Стефановић 2008: 133, 142.
} 
телефон, чији референти мање наликују човеку, а у другој - енглеског пасива.

Када се ради о оперативном систему и телефону, ова им. у НовК нема дужи акузатив, ни као властита ни као заједничка. Изузеци су тражени посебно, у „форумском” корпусу (ФК), сачињеном од порука са њом из периода 2007-2010. на форуму Бенчмарк (〈http://forum.benchmark.rs〉).

АНДРОИД („,ОПЕРАТИВНИ СИСТЕМ, ТЕЛЕФОН”)

\begin{tabular}{|c|c|c|}
\cline { 2 - 3 } \multicolumn{1}{c|}{} & НовК & $\mathbf{\Phi K}$ \\
\hline Аниматни акузатив & & $\mathbf{3 , 7 7 \%}(15)$ \\
\hline Инаниматни акузатив & $\mathbf{1 0 0 \%}$ & $\mathbf{9 6 , 2 3 \%}(383)$ \\
\hline
\end{tabular}

Чини се да се у ФК ова именица најчешће односи на оперативни систем, али то није увек једноставно доказати:

[priest77:] Citiram korisnika: LazaNS

[,,]Odlicno, dakle iOS [систем] sam po sebi nema prednosti nad Androidom [систем?], konacno nesto da iscuapamo["]

$\mathrm{Na}$ androidu [телефон?] iz starta ce ti prekipeti koliko je ruzno odradjen UI, crnolsivo. [...] cim otvoris bilo koju aplikaciju na iPhone [телефон] otvara se i zatvara se sa animacijom[...].

[...] kako stvari stoje i dalje ce iPhone biti u debeloj prednosti, jer uglavnom kada nesto novo izadje, prvo se to pojavi za iPhone pa kasnije mozda i za android [телефон?]. Apple prodaje najvise aplikacija za mobilne telefone [...].

[sysninja:] Sad sam definitivno siguran da ti nisi nikada koristio Android [систем?].

Референција је важна зато што облик ак. јд. по свој прилици зависи од тога да ли се ради о систему или о телефону - од 15 изузетака у ФК, за 8 би се могло тврдити да се односе на телефон, а за 1 да се односи на систем, док је међу 383 инаниматна примера однос скоро обрнут (30 : 140). Склоности и ставови аутора не могу објаснити ову тенденцију ни саму појаву изузетака, бар не на узорку од 15 примера, јер ниједан аутор који се у грађи јавља са 2 или више реченица не користи искључиво дужи акузатив, нпр.:

driver:

...ili su svi kupili Androida zbog 6 USBa

[УП.:] Problem ovde je u tome shto iOS urediaj ne mozesh tek tako da kupish, [...] dok Symbian, Android i sve ostalo imash u Megamarketu na 20 rata[...]

\section{priest77:} krenuli u rat

[...] ali ja kada bi napisao takvu izjavu, odmah bi ovi shto su uzeli Androida na 50 rata

[УП.:] Ako nekome smeta iTunes, [...] ...onda lepo neka kupi android za upola cene i niko mu ne brani da misli da ima najbolji telefon [...].

[Систем Андроид је бесплатан.] 
Ако су наведене пропорције репрезентативне, могле би происходити отуда што је телефон материјалан, конкретан ${ }^{17}$ и бројив, а систем апстрактнији. Истина, систем има извесну конкретност, будући да се им. андроид у том значењу јавља у множини:

u cemu je razlika izmedju ovih svih androida [= верзијâ Андроида] za hd2 [модел телефона] na xda [сајт].

5.3. Бот. У случају значења „програм”, удели краћег и дужег акузатива скоро су изједначени и забележен је минимални пар (уп. 5.1):

Njihov zadatak bio je da u programskom jeziku Java naprave 'bot'/‘bota' koji je sposoban da igra kartašku igru Texas hold'Em poker. (Б92/Телеграф)

$$
\text { БОТ }(, \text { (РОГРАМ”) }
$$

\begin{tabular}{|c|c|}
\cline { 2 - 2 } \multicolumn{1}{c|}{} & НовК \\
\hline Аниматни акузатив & $\mathbf{5 2 , 6 3 \%}(10)$ \\
\hline Инаниматни акузатив & $\mathbf{4 7 , 3 7 \%}(9)$ \\
\hline
\end{tabular}

Аниматност потиче од аутономије коју програм има у обављању задатка (као што је слање порука и одговарање на њих), али и од тога што је сврха оваквог програма да имитира понашање стварних корисника: (Курир)

Ono što je izvesno je da je bota teško razotkriti, odnosno razlikovati od pravog posetioca.

Очекивано, ова им. је увек аниматна (3/3) кад означава интернетског пропагандисту, нпр.: вости)

Ali, odnedavno samo jedna stranka ima „bota” koji je nagrađen za svoj angažman. (Ho-

Такође, у SF корпусу нађена су 2 аниматна акузатива (1 у полусл.) у значењу „робот”. ${ }^{18}$

Значење „вештачки играч у видео-игри” потврђено је једним примером. Његова аниматност не чуди, пошто је такав бот отеловљен у виртуелној средини.

Naučnici su razvili takozvanog ,bota” za igru Unreal Tournament 2004 (veštačku inteligenciju koja upravlja likom u igri) koja se više ponaša kao čovek od polovine živih učesnika takmičenja „BotPrize”. (Б92)

5.4. ДРоид. Лексема је посведочена само у НовК. Однос аниматно : инаниматно је 7 : 1 (полусл.). Инаниматни акузатив јавио се у апозицији при им. која се не деклинира:

\footnotetext{
${ }^{17}$ УП. Стефановић 2008: 69.

${ }^{18}$ Им. бот је и творена од им. робот (суптракцијом).
} 
Nemačka kompanija First Androids [NSFW] dizajnirala je Andy, seks-droid. (Лепота и здравље)

Дроид је и (у НовК инаниматни) назив за врсту телефона са оперативним системом Андроид.

5.5. ДРон. Није нађено довољно материјала да се направи стручни корпус за ову именицу, јер експерти преферирају изразе попут „unmanned aircraft system” („UAS”; уп. 5.2).

Имајући у виду да је реч о уживо контролисаном ентитету, унеколико изненађује разлика у односу на аватар 2 (в. 5.1), тим пре што се намеће позитивна корелација конкретности и аниматности (в. 5.2). Краћи акузатив преовладава вероватно зато што дронови својим обликом и понашањем не подсећају на човека и зато што код им. дрон нема притиска каквог аниматнијег значења.

\begin{tabular}{|c|c|}
\cline { 2 - 2 } \multicolumn{1}{c|}{} & НовК \\
\hline Аниматни акузатив & $\mathbf{8 , 9 6 \% ( 6 3 )}$ \\
\hline Аниматни акузатив - само који & $\mathbf{0 , 1 4 \% ( 1 )}$ \\
\hline Инаниматни акузатив & $\mathbf{9 0 , 9 0 \% ( 6 3 9 )}$ \\
\hline
\end{tabular}

Неки модели дрона донекле су аутономни у односу на вољу пилота:

[...] kamere su vrhunske, stabilizacija neverovatno dobra, a sami dronovi su sve pametniji. Ako želite da dresirate vrhunskog drona, onda preskočite prethodne generacije [...]. [...] Sada su [pokretanje i vraćanje] skoro potpuno automatske radnje, a Obstacle Sensing System obezbediće da se dron bezbedno i najkraćim putem vrati, [...] Active track omogućava praćenje bilo kog objekta $[\ldots]$ bez potrebe da objekat posebno označavate $[. .$.$] . Phantom 4$ će pratiti objekat bez greške $[\ldots]$ (PC Press, 4. 4. 2016)

Ипак, та се особина не може везивати само за дужи акузатив:

Ova letelica koristi [...] senzore kako bi se [...] stabilizovala, dok procesor [...] upravlja [...] veštačkom inteligencijom kako bi otkrio i pratio prepreke i lica.

[...] ona jednostavno koristi prepoznavanje lica [...] da bi sama lebdela [...].

[...] možete koristiti aplikaciju [...] kako bịpostạvilị dron ụ željẹni položạj [...]. (Телеграф, 4. 5. 2016)

Пет изузетака је одговор на формалне стилске захтеве (нпр. „[...] da uneseš i drona i slona [...]” /Е-новине/, вероватно и „I SONY DRONA [: коња] ZA TRKU IMA”/Телеграф/).

Аниматни акузативи не могу се објаснити новином именице (има је у чланцима из 2010) или неупућеношћу аутора:

Sada već svako može kupiti drona, a to znači da postoji puno [...] neiskusnih pilota.

$[\ldots]$

Na Tviteru Perel je objavio da je neko, ubrzo nakon incidenta, došao da potraži dron. (Курир, 8. 4. 2016) 
С друге стране, 18 од 59 немаркираних изузетака потиче из 16 вести са Телеграфа, што је несразмерно доприносу тог сајта укупном броју линкова (1773 без мањих допуна):

\begin{tabular}{|c|c|c|}
\cline { 2 - 3 } \multicolumn{1}{c|}{} & $\begin{array}{c}\text { Удео у укупном броју } \\
\text { линкова }\end{array}$ & $\begin{array}{c}\text { Удео текстова са изузетком } \\
\text { у укупном броју линкова }\end{array}$ \\
\hline Блиц & $26,90 \%(477)$ & $0,39 \%(7)$ \\
\hline Курир & $10,54 \%(187)$ & $0,45 \%(8)$ \\
\hline Телеграф & $7,56 \%(134)$ & $\mathbf{0 , 9 0 \% ( 1 6 )}$ \\
\hline
\end{tabular}

Ови текстови најчешће не носе податак о аутору или редактору. У случају Телеграфа, то су биле бар две особе („D. Čavić”, „М.M.”). 4 од 7 текстова са дужим акузативом из Блица потписује „T.Vujović” или „T.V.”, али има и других новинара („I.D.”, „T. S.”).

Примамљива је теза да су се изузеци груписали по таблоиднијим порталима (уколико их је лако идентификовати), као што су 24 сата (3) и Ало (3). Додуше, дужи акузатив именице дрон нађен је и на другим сајтовима - Б92 (3), Tango Six (2), ИТсвет (1), PC Press (1), Политика (1)...

2 неочекивана облика јавила су се у апозицији при аниматном акузативу (нпр. „Američka vojska testirala je prvog kopnenog robota, drona [...]”/Курир/), a 1 у апозицији при инаниматном (,„[...] napravila je Volocopter VC..200, prvog drona koji [...]” /Телеграф/; у истом тексту: „sa Volocopterom”).

5.6.1. КиБорг. Сви примери из SF корпуса аниматни су (6/6). Једини изузетак у НовК (1/34) не делује убедљиво:

Naučnici napravili kiborg raže!

Međunarodni tim istraživača razvio je jezivo realnog robota [jд.] Stingra koji pomera granicu između životinja i mašina.

[...] Oni su testirali svetlo-driven navigacioni sistem tako što su provlačili kiborga Stingrai kroz prepreke. (Блиц)

5.6.2 Клон. У грађи се често говори о „клону” телефона, аутомобила, сајта и сл., али метафора̂ има и међу инстанцама које се односе на жива бића (нпр. „Дилановог клона”, о другом музичару).

КЛОН

\begin{tabular}{|c|c|c|c|}
\cline { 2 - 4 } \multicolumn{1}{c|}{} & НовK & SF корпус & НК \\
\hline Аниматни акузатив & $\mathbf{8 7 , 3 0 \% ( 5 5 )}$ & $\begin{array}{c}\mathbf{1 0 0 \%} \\
(5+3 \text { полусл. })\end{array}$ & $?$ \\
\hline Инаниматни акузатив & $\mathbf{1 2 , 7 0 \% ( 8 )}$ & & $?$ \\
\hline
\end{tabular}




\section{КЛОН ${ }_{2}$ (,ИДЕНТИЧАН НЕЖИВИ ЕНТИТЕТ”)}

\begin{tabular}{|c|c|}
\cline { 2 - 2 } \multicolumn{1}{c|}{} & НовК \\
\hline Аниматни акузатив & $\mathbf{2 7 , 0 3 \%}(10)$ \\
\hline Инаниматни акузатив & $\mathbf{7 2 , 9 7 \% ( 2 7 )}$ \\
\hline
\end{tabular}

Различити акузативи јавили су се у веома сличним окружењима:

Jạpạnșịi naučnici nameravaju da naprave klona duboko zamrznutog mamuta iz Rusije. (Блиц, 2011)

Jụ̆çnọọọrejș̣ị i ruski naučnici nameravaju da zajedničkim istraživačkim radom naprave klon mamuta, životinje koja je izumrla pre 10.000 godina. (Нови магазин, 2012)

5.6.3. Јединице киборг и клон 1 аниматније су због делимичне одн. потпуне органичености њихових референата.

\section{7. РоБот}

\begin{tabular}{|c|c|c|c|}
\cline { 2 - 4 } \multicolumn{1}{c|}{} & НовК & SF корпус & НК \\
\hline Аниматни ак. & $\mathbf{9 4 , 0 8 \% ~ ( 8 9 0 ) ~}$ & $\mathbf{1 0 0 \%}(669)$ & $\mathbf{1 4 \%}(14)$ \\
\hline & $\begin{array}{c}\mathbf{4 , 0 2 \%}(38) \\
\text { Инаниматни ак. }\end{array}$ & $\begin{array}{c}\mathbf{0 , 5 3 \%}(5 / \text { полу/ } \\
\text { сложеница) }\end{array}$ & \\
\hline $\begin{array}{c}\text { Инаниматни ак. - само } \\
\text { који и један }\end{array}$ & $\mathbf{1 , 2 7 \% ( 1 2 )}$ & & \\
\hline
\end{tabular}

НовК садржи бар 6 паралелних употреба унутар истог текста, као и минимални пар:

Amerikanci napravili robot koji ubija virus ebole za dva minuta!

$[\ldots]$

Američka kompanija «Kseneks»[...] iznela je revolucionarnu tvrdnju da je napravila robota ubicu ebole, piše Dejli mejl. (Курир)

Postavlja se pitanje zašto NASA nije poslala na Mars savršeno sterilisan robot / sterilisanog robota [о роверу Кјуриосити]? (Актер, Новости, РТВ / Нови магазин)

10 инаниматних акузатива (9 им. + 1 односна зам.) и 2 паралелне употребе потичу из Политике.

У апозицији при инаниматном акузативу јавила су се најмање 2 неочекивана облика, али и 3 очекивана.

Маркес је још 1995. запрепашћен што су тадашњи репортери пронашли сопствени сурогат, робот који ће уместо њих обављати посао. (Политика)

Gojko Panić i Darko Birač, učenici [...] iz Kaća, predstavili su gradonačelniku Novog Sada Milošu Vučeviću svoj izum, robota "Finch" sa kojim su osvojili prvo mesto [...]. (Данас) 
Мало учешће краћег акузатива налаже да се размотри фактор грешке при куцању, редиговању или превођењу текста, иако је то тешко утврдити.

To je bilo pre osam godina i tada sam napravio prvog „Eko-robot”, koji je na sebi imao samo kameru. [...] na prednjem delu „Eko-robota” [...] (Блиц; пример је избачен из статистике)

Према двама примерима нађен је вероватни страни извор са пасивом, али према другим трима - страни извор са активом.

Osim činjenice da će da trči, skače, vozi se i buši podlogu na kojoj se nađe, ovaj robot moći će da kontroliše samo jedan čovek - i to preko Nintendo konzole i popularnog Iks-boksa. (Блиц, 5. 2. 2012)

[УП.:] But what's even more mind bending is how, in the future, it could be controlled externally by a human - using an Xbox Kinect or Nintendo Wii. (Daily Mail, 2. 2. 2012)

Sledeće godine, TEPCO planira da pošalje u zonu amfibijski robot radi daljeg istraživanja tri reaktora, u kojima su se otopila nuklearna jezgra. (Блиц, 14. 4. 2015)

[УП.:] ТЕРСО plans to send in a different, amphibious robot next year for further investigation of the three reactors that suffered meltdowns. (Daily Mail, 13. 4. 2015)

По један инаниматни ак. дошао је у управним говорима роботичара из Института Лола, уметника, Драгана Илића (зам. који) и 17-годишњег конструктора робота, за ког је речено да ради без научне литературе. Друга два саговорника новинара, према истим двама текстовима, користила су и аниматни акузатив. У случају трећег саговорника, а сада и одговарајућег новинара, аниматни је акузатив можда употребљен јер је референт био сложенији:

- [...] Прошле године направио сам робот „М-2“, који има покретну камеру која може да снима. [...]

[Уп.:] - [...] Када бих имао материјал, могао бих да направим правог робота који би помагао инвалидима. [...]

Ова три (Политикина) текста од различитих су аутора.

У једној се реченици ак. споја фото-робот јавио с наставком мада је јасно да је аутор мислио на цртеж:

Духовити цртач из хрватске полиције направио је идеалног фото-робота убице Иве Пуканића: не личи ни на кога. Таква ликовна оригиналност само привидно је водила брзом расплету, [...]. (Политика)

ФОТО-РОБОТ („ЦРТЕЖ”)

\begin{tabular}{|c|c|c|}
\cline { 2 - 3 } \multicolumn{1}{c|}{} & НовК & НК \\
\hline Аниматни ак. & $\mathbf{7 , 6 0 \%}(6)$ & $?$ \\
\hline Инаниматни ак. & $\mathbf{9 2 , 4 0 \% ( 7 3 )}$ & $?$ \\
\hline
\end{tabular}


Типичном индустријском роботу од аниматности одузима то што није хуманоидан $^{19}$ и што не може променити своју локацију. Роботичар је тога (и сличног) свеснији него лаик, па је природно што у техничкој литератури преовладава краћи акузатив.

Седам текстова из НК доноси паралелну употребу. Аутор прве наведене књиге у предговору најављује „način pisanja blizak publicističnom” у „nekim segmentima knjige, posebno uvodnim"; дужи се акузатив среће на 23, 39, 115, 187. и 222. од 292 странице. У трећем тексту, оба изузетка су инстанце синтагме „предности човека у односу на робота”.

\begin{tabular}{|c|c|c|}
\hline Извор из НК & $\begin{array}{l}\text { Аниматни } \\
\text { ак. }\end{array}$ & $\begin{array}{c}\text { Инаниматни } \\
\text { ак. }\end{array}$ \\
\hline V. Potkonjak, Robotika, 1996. & 5 & $21+1$ (зам.) \\
\hline M. Popović, Senzori u robotici, 1996. & 3 & 1 \\
\hline $\begin{array}{l}\text { Скрипта из индустријске роботике (〈http://ftn. } \\
\text { mrdnise.com/skripte-35-0-2.php») }\end{array}$ & 2 & 19 \\
\hline [D. Milutinović,] Industrijski roboti (predavanja) & 1 & 11 \\
\hline $\begin{array}{l}\text { M. Raković, Sinteza i realizacija dvonožnog hoda } \\
\text { putem primitiva, } 2013 \text {. }\end{array}$ & 1 & 1 \\
\hline $\begin{array}{l}\text { I. Nikolić, V. Čolić, Izabrana poglavlja mehanike } \\
\text { robota, } 1999 .\end{array}$ & 1 & 10 \\
\hline $\begin{array}{l}\text { М. Лазаревић et al., Динамика и управљање кре- } \\
\text { тањем робота, } 2014 .\end{array}$ & 1 & 2 \\
\hline B. Borovac et al., Zbirka zadataka iz robotike, 2002. & $\mathbf{0}$ & 10 \\
\hline $\begin{array}{l}\text { J. Tunić, Primjena SCARA robota za posluživanje } \\
\text { obradnih sustava, } 2007 \text {. }\end{array}$ & $\mathbf{0}$ & 7 \\
\hline M. Ćućilović, Industrijski manipulatori, 2010. & $\mathbf{0}$ & 3 \\
\hline
\end{tabular}

6. ЗАкључци. Ранија дескрипција грађе из српског са им. робот (в. 1.1) начелно је потврђена. У погледу изузетака, мада је српски SF корпус био хомоген, резултати из 5.7 сличнији су стању у руском (в. 1.2).

За дистрибуцију су најзначајније особине референта. Колебање је велико када је референт нематеријалан и (а) несамосталан (аватар $)$ или (б) без виртуелног тела $\left(\sigma_{1}\right)$; другде се уочавају стабилне тенденције.

Одлике референта може надјачати формална инерција (аналогија), која је вероватно узроковала изузетке у апозицијама (в. 5.4, 5.5; уп. 5.1, 5.2, 5.7) и поменути ак. фото-робота (уп. им. робот; в. 5.7), а ту су и фактори попут

\footnotetext{
${ }^{19}$ Индустријски робот може имати облик људске руке, али део аниматног ентитета није аниматан, нпр. врат, прст (Дешић 1997: 187).
} 
аутора, сајта и стилских поступака (5.5). Међутим, предиктивна вредност ових ванреференцијских критеријума углавном је врло мала.

\section{ЛИТЕРАТУРА}

Баyep 2003: L. Bauer, Introducing Linguistic Morphology, Washington D.C.: Georgetown University Press.

Дешић 1997: М. Дешић, „Акузатив једнине именица мушког рода и полисемија", НССУВД, 26/2, 185-193.

Драгићевић 2010: Р. Драгићевић, Лексикологија српског језика, Београд: Завод за уџбенике.

Ицкович 1980: В. А. Ицкович, „Существительные одушевленные и неодушевленные в современном русском языке (Норма и тенденция)", Вопросы языкознания, 4, 84-96.

Кристал ${ }^{6}$ 2008: D. Crystal, A Dictionary of Linguistics and Phonetics, Malden, MA: Blackwell Publishing.

Марковић 22013: I. Marković, Uvod u jezičnu morfologiju, Zagreb: Disput.

OP: Oxford Advanced Learner's Dictionary. «http://www.oxfordlearnersdictionar ies.com>, 5.11.2016.

Стевановић 51986: М. Стевановић, Савремени српскохрватски језик. 1, Београд: Научна књига.

Стефановић 2008: М. Стефановић, Категорија аниматности у српском и руском језику, Нови Сад: Академска књига.

Danilo Aleksić

ANIMACY AND LIVING MACHINES

Summary

The subject of research is the variation of the accusative singular form in the paradigms of Serbian masculine $1^{\text {st }}$ declension nouns which denote (relatively) autonomous artificial beings, such as робот. The paper provides relative frequencies of the competing forms, as well as the semantic and formal interpretations of the data. Special attention is paid to the less frequent, unexpected accusative forms.

Key words: morphology, nouns, accusative, animacy, animate, inanimate, robot. 